\title{
COMPARATIVE CHARACTERISTICS OF THE PARAMETERS' CHANGES OF SKIN AND FAT FLEXURES THICKNESS OF EXTREMETIES AT YOUTH UNDER THE CONDITION OF HIGHER EDUCATION
}

10.36740/WLek202010120

\author{
Nataliia S. Alekseyenko', Vitalii M. Andriychuk' ${ }^{1}$, Ruslan V. Radoha ${ }^{1}$, Lyudmila V. Fomina' ${ }^{1}$, Larysa Ya. Fedoniuk ${ }^{2}$ \\ 'NATIONAL PIROGOV MEMORIAL MEDICAL UNIVERSITY, VINNYTSIA, UKRAINE \\ 2. HORBACHEVSKY TERNOPIL NATIONAL MEDICAL UNIVERSITY, TERNOPIL, UKRAINE
}

\begin{abstract}
The aim: To determine and compare annual changes of skin and fat flexures thickness of the extremities of rural and urban youths during training at a university. Materials and methods: 200 practically healthy young men (100 residents of the village, 100 residents of the city) were studied at the 1 st, 2 nd and 3 rd courses of their education at the University of Life Safety by means of Shephard R. method.

Results: Based on the data we' ve got, the annual reduction of most indicators of the thickness of the fat layer of the upper and lower extremities was supervised. The most substantial decrease was supervised during the first year. The intra-group annual changes were significantly smaller throughout the first year of study, both in the rural and urban groups. Conclusions: Significant differences in intra-group and inter-group indicators were found between youth living in the city and rural residents. In addition, significant differences were found in the thickness of the skin and fat flexures in youngers of both groups during the three years of education process.
\end{abstract}

KEY WORDS: fat thickness, extremities, adolescence, rural residents, urban residents

Wiad Lek. 2020;73(10):2214-2218

\section{INTRODUCTION}

Exogenous factors are believed to be a set of environmental issues that affect the human body $[1,2,3]$. These include: natural, environmental and socio-economic factors. Among them, a special place is occupied by day mode and diet, motor mode, emotional load [4]. These exogenous factors, together with others, are an integral part of the pedagogical process, which is a complex system of educational and training-production activity organization; is defined by educational, scientific, behavior plans and includes: lessons, lectures, laboratory classes, brakes between classes, educational practice, industrial practice, research, excursions, sports competitions, transportation or transitions to the venue of events, etc. [5]. At the time of admission to higher education, most boys and girls reach only a certain degree of physical maturity. However, the complete process of physical and mental maturation continues [6]. Human development goes through a series of successive stages, each of which is characterized by its traits, structure of mental activity, peculiarities of forming relationships of mental processes and personality traits, the relationship of the individual with the environment. Junior students are not only different in age and development, but also in their territorial affiliation with the city or village. Given the complexity and importance of the educational process for shaping the personality of the future specialist, it is impossible to manage the educational activity and process without knowing and taking into account the peculiarities of development in the youthful period $[7,8]$.

Thus, today there are scientific works in which the influence of endogenous and exogenous factors on anthropometric parameters of young men is considered $[9,10]$. However, there is no work that identifies and compares annual changes in somatometric parameters, namely, the thickness of the upper and lower limb fat layers of rural and urban residents while studying at higher education institutions.

\section{THE AIM}

To determine and compare annual changes of skin and fat flexures thickness of the extremities of rural and urban youths during training at a university.

\section{MATERIALS AND METHODS}

Experimental studies were performed on the basis of the School of Civil Protection of Lviv State University of Life Safety. The school is the higher education institution (HEI) of the first level of accreditation of the State Emergency Service of Ukraine (SESA) in which the young men under study. The training has its own specificity related to the service in the units of the SES. All young people live in a 
dormitory and their daily schedule was drawn up in accordance with the Charter of the Armed Forces of Ukraine, the educational process and physical activity were regulated. We carried out a longitudinal (on the 1st, 2 nd courses of study) determination of the thickness of the fat layer of 100 young men who lived in the village and 100 young citizens. We performed comparison between groups of rural and urban residents and analyzed particularities of these indicators in terms of the educational process within three years of training. The determination of the thickness of the fat layer was done according to the method of Shephard R. $[11,12,13]$. Statistical processing of the obtained results was carried out in the standard software package "STATISTICA 6.1" with the use of parametric and non-parametric evaluation tools. We determined the normality of the distribution of the data for each of the variations obtained, the average values for each of the studied traits, standard errors and deviations. Student t-test was used to evaluate differences between groups. The difference was considered significant at a worth level of $\mathrm{p}<0.05$.

\section{RESULTS AND DISCUSSION}

In the study of the thickness and fat layer of the upper extremity the following indicators were determined. The thickness of the shoulder back surface fat layer on the first course residents' training was 4,28 $\pm 1,37 \mathrm{~mm}$ for villages, through the same indicator for city residents was smaller and amounted to $3,92 \pm 1,11 \mathrm{~mm}$. It should be noted, that this thickness skin -fat layer of the village inhabitants was meaningfully higher by $0.36 \mathrm{~mm}$ in contrast with its citizens $(t=2,01$ at $p<0,05)$. During the second year of study the certain parameter for village dwellers decreased by $0.70 \mathrm{~mm}$ and was equal to $3,58 \pm 0,10 \mathrm{~mm}$, as for the city dwellers, it declined to $3,45 \pm 0,10 \mathrm{~mm}$. In the third year, the thickness of the fat layer on the back surface of the shoulder of the inhabitants of the village and the city again decreased - up to $3.55 \pm 0.11 \mathrm{~mm}$ and $3.43 \pm 0.10$ $\mathrm{mm}$ correspondently.

The average change of the fat layer thickness on the shoulder back surface of the village youth in the first year of study was $(-0.70 \pm 0.09) \mathrm{mm}$ with a minimum value of $(-4.50) \mathrm{mm}$ and a maximum gained till $1.00 \mathrm{~mm}$. In the second year of study, the difference in thickness of the fat layer on the back surface of the shoulder for the villagers was $(-0.03 \pm 0.02) \mathrm{mm}$, with a smallest amount and greatest value of $\pm 1.00 \mathrm{~mm}$. The following indicators were typical of city dwellers: average $-(-0.01 \pm 0.01) \mathrm{mm}$, smallest amount $-(-0.50) \mathrm{mm}$, greatest $-1.00 \mathrm{~mm}$.

The thickness of the fat layer on the shoulder back surface for the village residents' decreased by $0.73 \mathrm{~mm}$ during the study, with the main decline observed in the first year of study, and the intra-group annual change of this parameter in the first year of study was notably smaller by $0.67 \mathrm{~mm}$ compared to the annual change in the second year $(t=7.43$ at $\mathrm{p}<0.05)$. As for the towns, the parameter decreased by $0.48 \mathrm{~mm}$ and the prominent decrease was supervised in the first year of study. The annual change of this parameter during the first year of study was considerably smaller by $0.46 \mathrm{~mm}$ compared to the annual change in the second year $(t=7.07$ at $\mathrm{p}<0.05)$.

The intergroup annual change of the fat layer thickness of the shoulder back surface during the first year of study for the villagers was extensively smaller by $0.23 \mathrm{~mm}$ compared to the city inhabitants $(t=2.09$ at $p<0.05)$. In the second year of study, the inter-group annual change of this thickness among the villagers was smaller by only 0.01 $\mathrm{mm}$ compared to the locals, and there was no significant difference.

The thickness of the fat layer on the front surface of the shoulder during the first year of study was $2.30 \pm 0.27 \mathrm{~mm}$ for the residents of the village; as for the population of the city, it was smaller and equaled $1.94 \pm 0.56 \mathrm{~mm}$. During the second-year study, the parameter decreased by $0.43 \mathrm{~mm}$ for population of villages and equaled $1.87 \pm 0.37 \mathrm{~mm}$, while the city residents' decreased to $1.83 \pm 0.37 \mathrm{~mm}$. In the third year, the thickness of the fat layer on the front surface of the shoulder of the inhabitants of the villages and the cities again decreased: in the peasants - up to $1.86 \pm 0.36 \mathrm{~mm}$, in the locals - up to $1.81 \pm 0.37 \mathrm{~mm}$.

The average change in the thickness of the fat layer on the front surface of the shoulder for countryman youth in the first year of study was $(-0.43 \pm 0.21) \mathrm{mm}$ with a minimum value of $(-2.00) \mathrm{mm}$ and a maximum gain of $0.50 \mathrm{~mm}$. This annual change in boys from the city was equal to $(-0.11 \pm$ $0.04) \mathrm{mm}$ with minimum and maximum values $(-3.00)$ $\mathrm{mm}$ and $0.50 \mathrm{~mm}$, respectively.

In the second year of study, the difference in thickness of the fat layer on the front surface of the shoulder for the villagers was $(-0.03 \pm 0.01) \mathrm{mm}$ with a minimum and maximum value of $\pm 0.50 \mathrm{~mm}$. The following indicators were characteristic of city dwellers: average $-(-0.02 \pm 0.02)$ $\mathrm{mm}$, minimum - $(-0.50) \mathrm{mm}$.

The thickness of the fat layer on the front surface of the cottager residents' shoulder decreased by $0.46 \mathrm{~mm}$ during the study, with the main decline was observed in the first year of study, and the intra-group annual change of this parameter in the first year of study was less by $0.40 \mathrm{~mm}$ compared to the annual change in the second.

Among urban inhabitants - decreased by $0.13 \mathrm{~mm}$ and the main lessen was observed in the first year of study. The annual change of this parameter during the first year of study was appreciably smaller by $0.13 \mathrm{~mm}$ compared to the annual change in the second year $(\mathrm{t}=2.02$ at $\mathrm{p}<0.05)$.

The intergroup annual change in the thickness of the shoulder anterior layer during the first year of education of the rustic residents was smaller by $0.32 \mathrm{~mm}$ compared to city inmates, and in the second year of the study the intergroup annual change of this thickness in the villagers was greater by only $0.01 \mathrm{~mm}$ compared to the townspeople. It should be noted that this annual change in the first and the second year of study, comparing the groups of young people, was not considerably different.

The thickness of the fat layer in the upper third of the forearm in the first year of study-villagers was $1.69 \pm 0.30$ $\mathrm{mm}$, the indicator for urbans was smaller and equaled to 
$1.63 \pm 0.37 \mathrm{~mm}$. During the second-year study, the measured size of the village and town residents decreased by $0.04 \mathrm{~mm}$ and was $1.64 \pm 0.25 \mathrm{~mm}$ and $1.59 \pm 0.23 \mathrm{~mm}$, respectively. By the third year, the thickness of the fat layer in the upper third of the forearm of the village inhabitants did not change, and for the inhabitants of the city, decreased to $1.58 \pm 0.21 \mathrm{~mm}$.

The average change of the upper third foramen thickness fat layer for the village youth in the first year of education was $(-0.04 \pm 0.02) \mathrm{mm}$ with a smallest amount $(-2.00) \mathrm{mm}$ and a maximum gained to $0.50 \mathrm{~mm}$. This annual change in young men from the cities was equal to $(-0.04 \pm 0.03)$ $\mathrm{mm}$ with minimum and maximum values $(-3.00) \mathrm{mm}$ and $0.50 \mathrm{~mm}$, respectively.

By the second year of study, the difference in the fat layer thickness of the upper third of forearm for citizens was $(-0.01 \pm 0.01) \mathrm{mm}$ with a minimum value of $(-0.50) \mathrm{mm}$. For the villagers this indicator has not changed.

The thickness of the fat layer in the upper third area of the forearm for the plowmen decreased by $0.04 \mathrm{~mm}$ during the study, with a reduction observed only in the first year of study, and the intra-group annual change of this parameter was radically smaller by $0.04 \mathrm{~mm}$ compared to the annual change of the second year $(\mathrm{t}=2.23$ at $\mathrm{p}<0.05)$. Towns' result decreased by $0.05 \mathrm{~mm}$ and the main decrease was observed on the first education year. The annual change of this parameter in the first year of study was less by 0.04 $\mathrm{mm}$ compared to the annual change in the second year.

The inter-group annual change in the thickness of the fat layer of the upper third of the forearm in the first year of study of the inhabitants of the villages and the cities was the same, and in the second year of study the inter-group annual change of the villages was greater by only $0.01 \mathrm{~mm}$ compared to the locals. It should be noted that this yearon-year change in the first and second year of study did not make a substantial difference when comparing youth groups.

The thickness of the fat layer on the thigh front surface in the first year of education among the villagers was $3.94 \pm 1.02 \mathrm{~mm}$, and the parameter for the city residents was smaller and equal to $3.64 \pm 1.03 \mathrm{~mm}$. It should be noted that this thickness of the skin-fat layer in the villagers turned out to be significantly greater by $0.30 \mathrm{~mm}$ compared to the locals $(t=2.08$ at $\mathrm{p}<0.05)$. During the second-year study, the size of the village residents decreased by 0.44 $\mathrm{mm}$ and equaled $3.50 \pm 0.97 \mathrm{~mm}$, while the residents of the city decreased to $3.37 \pm 0.90 \mathrm{~mm}$. In the third year, the thickness of the fat layer on the front surface of the young thigh decreased: respectively - to $3.48 \pm 0.96 \mathrm{~mm}$ in the peasants and $3.33 \pm 0.86 \mathrm{~mm}$ in the locals.

The average fat layer thickness change of the thigh front surface for villages youths in the first year of study was $(-0.44 \pm 0.06) \mathrm{mm}$ with a minimum value of $(-2.00) \mathrm{mm}$ and a maximum value of $1.00 \mathrm{~mm}$. This annual change in young men from the city equaled $(-0.27 \pm 0.06) \mathrm{mm}$ with minimum and maximum values $-1.00 \mathrm{~mm}$ and $1.00 \mathrm{~mm}$, respectively.

During the second year of study, the difference in thickness of the fat layer on the anterior thigh surface for the villagers was $(-0.02 \pm 0.01) \mathrm{mm}$ with a minimum and maximum value of $\pm 1.00 \mathrm{~mm}$. The following indicators were characteristic for city dwellers: average - $(-0.04 \pm$ $0.02) \mathrm{mm}$, minimum - $(-1.00) \mathrm{mm}$, maximum $-1.00 \mathrm{~mm}$.

The thickness of the fat layer on the anterior surface of the thighs of the village residents decreased by $0.46 \mathrm{~mm}$ during the study, with the main decrease observed in the first year of study, and the intra-group annual change of this parameter in the first year of study was significantly smaller by $0.42 \mathrm{~mm}$ compared to the annual change in the second. year $(t=6.20$ at $\mathrm{p}<0.05)$. As for the townspeople decreasion of the parameter was by $0.31 \mathrm{~mm}$ and reduction was observed in the first year of study. The annual change of this parameter in the first year of study was significantly smaller by $0.23 \mathrm{~mm}$ compared to the annual change in the second year $(\mathrm{t}=3.22$ at $\mathrm{p}<0.05)$.

The inter-group annual change in the thickness of the fat layer on the front surface of the thigh in the first year of education of the village inhabitants was less by $0.17 \mathrm{~mm}$ compared to the city inhabitants. In the second year of study, the inter-group annual change of this thickness among the villagers was already greater by $0.02 \mathrm{~mm}$ compared to the locals. It should be noted that this annual change in the first and the second year of study when comparing the groups of young people did not a significant difference.

The thickness of the fat layer on the back surface of the tibia in the first year of study was $1.90 \pm 0.36 \mathrm{~mm}$ among the villagers, and for oppidan occupants, it was smaller and equaled to $1.85 \pm 0.34 \mathrm{~mm}$. During the second-year study, the size of the village and town residents decreased and equaled $1.72 \pm 0.23 \mathrm{~mm}$ and $1.75 \pm 0.25 \mathrm{~mm}$, respectively. Along the third year, the thickness of the fat layer on the back surface of the tibia of the villagers increased slightly and amounted to $1.74 \pm 0.25 \mathrm{~mm}$, while the city residents also increased to $1.77 \pm 0.25 \mathrm{~mm}$.

The average change in the thickness of the fat layer on the back surface of the tibia for village youths in the first year of study was $(-0.18 \pm 0.03) \mathrm{mm}$ with a minimum value $(-1.50) \mathrm{mm}$ and a maximum gained up to $0.50 \mathrm{~mm}$. This annual change in young men from the city equaled $(-0.10 \pm 0.03) \mathrm{mm}$ with minimum and maximum values $(-1.00) \mathrm{mm}$ and $0.50 \mathrm{~mm}$, respectively.

In the second year of study, the difference in the thickness of the fat layer on the back surface of the tibia for residents of villages and the cities was $0.02 \pm 0.01 \mathrm{~mm}$ with a maximum and minimum value $( \pm 0.50) \mathrm{mm}$.

The thickness of the fat layer on the back surface of the tibia of the village residents decreased by $0.16 \mathrm{~mm}$ during the study, with a diminution observed only during the first year of study, and the intra-group annual change of this parameter in the first year of study was significantly smaller by $0.20 \mathrm{~mm}$ compared to the annual change of the second. year $(t=5.38$ at $\mathrm{p}<0.05)$. In the townspeople - it decreased by $0.08 \mathrm{~mm}$ and achieved the main decline only in the first year of investigation. The annual change of this parameter in the first year of study was significantly smaller by $0.12 \mathrm{~mm}$ compared to the annual change in the second year $(\mathrm{t}=4.12$ at $\mathrm{p}<0.05)$. 
The inter-group annual change in the thickness of the fat layer on the back surface of the tibia in the first year of study of the village residents was less by $0.08 \mathrm{~mm}$ compared to the city residents, and in the second year of study, the inter-group annual change of the thickness in the city and village residents was the same. It should be noted that this year-on-year change in the first and second year of study did not make a significant difference, comparing youth groups.

The anthropometric parameters of young men were determined in the works of other authors. Thus, when comparing the data obtained by our research, of indicators of the thickness of the fat layer of boys, with the results of studies perfomed under the guidance of scientists and were executed on youth students and soldiers of Podolsk and Polissya regions, found that no significant difference was observed between the results $[14,15]$. Taking into account the fact that the young people we studied, were influenced by the educational process equally, which was due to the uniformity of approaches to the organization and intensity of physical and mental load, the status of belonging to rural or urban residence becomes a dominant factor. A grate quantity of works aimed to examining the effects of habitat and residence conditions on physiological and psychological parameters. Such studies were usually conducted on groups of students or students of individual educational institutions [16]. In contrast to the above works, we obtained the results of the study of the indicators of the thickness of the upper and lower extremities of rural and urban residents while studying at higher education institutions, and compared the changes of intragroup parameters during training. By the way, we identified intergroup variations of these indicators and the peculiarities of their changes in rural and urban youth during academic year.

\section{CONCLUSIONS}

When comparing the changes in the thickness of the extremity's fat layer under the condition of educational process we have identified the following differences:

All indicators of the upper and lower limb thickness fat layers of the young men in the first year of study were greater for the villagers than for the residents of the city.

During the educational process, most of the studied indicators decreased in both groups of boys.

Intergroup annual changes in the thickness of the upper and lower limb fat layers in the first year of rural residents' education were smaller compared to city residents, and the thickness of the fat layer on the back of the shoulder had significant differences.

Indicators of the component composition of the body weight of rural and urban youth are also warranted, with subsequent comparisons of their annual changes during study year.

\section{REFERENCES}

1. Remoundou K., Koundouri P. Environmental Effects on Public Health: An Economic Perspective. Int. J. Environ. Res. Public Health. 2009; 6(8):2160-2178.
2. Yoo S.J., Sawyerr 0., Tan W.L. The impact of exogenous and endogenous factors on external knowledge sourcing for innovation: The dual effects of the external environment. The Journal of High Technology Management Research. 2015; 26 (1):14-26.

3. Hetmaniuk I.B., Fedoniuk L.Ya., Zhulkevych I.V. et al. Microscopic and submicroscopic structure of the heart atria and auricles in condition of the experimental thermal trauma. Biointerface Research in Applied Chemistry. 2020; 10(2):5237-5242.

4. Andriychuk V.M. Osoblivosti zmin pozdovzhnih parametriv yunakivstudentiv v umovah pedagogichnogo procesu [Features of longitudinal parameters changes of young students in the conditions of pedagogical process]. World of biology and medicine. 2014; 4(47): 9-12 (In Ukrainian).

5. Serheta I.V., Dudarenko 0.B., Mostova 0.P. et all. The complex of psychohygienic measures correction of personality traits of HIV-infected men and evaluation of its effectiveness. Wiadomosci Lekarskie. 2018; 21(3):518-24.

6. Kurlyand Z.N. Pedagogika vishoyi shkoli [Pedagogy of high school]. Kiev: Science; 2010. 495 p. (In Ukrainian).

7. Vinué $G$. Anthropometry: An R package for analysis of anthropometric data. Journal of Statistical Software. 2017; 77(6):211-216.

8. Aberle N., Blekić M., Ivanis A., Pavlović I. The comparison of anthropometrical parameters of the four-year-old children in the urban and rural Slavonia, Croatia, 1985 and 2005. Antropol. 2009; 33(2): 34751.

9. Pomohaci M., Sopa I.S.The importance of anthropometry measurements in analyzing the impact of sports activities on students. Revista academiei forțelor terestre. 2017; 1(85):40-48.

10. Shaparenko P.P. Antropometrichna ta somatotipologichna harakterimstika praktichno zdorovih miskih pidlitkiv oboh statej ukrayinskoyi etnichnoyi grupi [Anthropometric and somatotypological characteristics of practically healthy urban adolescents of both sexes of the Ukrainian ethnic group]. Bulletin of Morphology. 2006; 8(1):339-41. (In Ukrainian).

11. Shephard R. Body composition in biological. Cambridge: Cambridge University Press; 1991.348 p.

12. Lescay N.R., Becerra A.A., González A.H. Anthropometry. Comparative analysis of technologies for the capture of anthropometric dimensions. Revista EIA. 2016; 26:47-59.

13. Shpakova N.A., Tyholaz V.0., Guminsky Yu.J. et al. Porivnyalnij analiz bazovih antropometrichnih pokaznikiv yunakiv (17-18 rokiv) 1994 - 2006 rokiv Podilskogo regionu Ukrayini [Comparative analysis of basic anthropometric indicators of boys (17-18 years) of 1994-2006 in the Podillya region of Ukraine]. Ukrainian morphological almanach. 2011;3:143-145. (in Ukrainian).

14. Gunas I.V., Blazhyevs`ka G.J., Prokopenko S.V. Korelyaciyi osnovnih pokaznikiv dermatoglifiki z obhvatnimi rozmirami tila u praktichno zdorovih miskih yunakiv i divchat meshkanciv Podilskogo regionu Ukrayini [Correlation of major dermatoglyphic indices with comprehensive body sizes in practically healthy urban boys and girls of Podilskyi region of Ukraine]. Biomedical and Biosocial Anthropology. 2005;4:14-17. (in Ukrainian).

15. Anczewska M., Charzynska K. Educational assessment of pupils in Poland. Educ. Journal. 2012; 9(1):11-9.

16. Bolsheva A., Sidorov D., Bogomolova E. Monitoring of physical development indicators of Nizhny Novgorod schoolchildren (1980-2012 years). In: [International Student Congress; 2014 July 10-12th; Graz, Austria]. 2014. Austria. 
The work is carried out within the framework of the initiative research work of the E. Pirogov Vinnytsia National Medical University (Vinnytsia, Ukraine) "0114U000990 "The influence of exogenous factors (socio-economic, ecological, geological, territorial) on anthropometric parameters and physiological indicators of adolescents»

\section{ORCID and contributionship:}

Nataliia S. Alekseyenko: 0000-0003-3137-7436 B,D

Vitalii M. Andriychuk: 0000-0001-8984-3028 A,C

Ruslan V. Radoha: 0000-0002-3531-8399 C

Lyudmila V. Fomina: 0000-0002-1695-3442 ${ }^{E, F}$

Larysa Ya. Fedoniuk: 0000-0003-4910-6888 ${ }^{E, F}$

\section{Conflict of interest:}

The Authors declare no conflict of interest

\section{CORRESPONDING AUTHOR}

Larysa Ya. Fedoniuk

Medical Biology Department,

I. Horbachevsky Ternopil National Medical University

Valova street 9, Ternopil, 46000, Ukraine

tel: +380673999143

e-mail: Fedonyuk22Larisa@gmail.com

Received: 14.06 .2020

Accepted: 26.08 .2020

A - Work concept and design, B - Data collection and analysis, C - Responsibility for statistical analysis, D-Writing the article, $\mathbf{E}$-Critical review, $\mathbf{F}$ - Final approval of the article 